\title{
The Collaborative Approach to Sustainability: A Model of Commissioning System Intervention in Supporting Multi-Stakeholder Partnerships from National to Global Levels
}

\author{
Camelia-Cristina Dragomir *(D) and Tiberiu Foris
}

check for

updates

Citation: Dragomir, C.-C.; Foris, T.

The Collaborative Approach to

Sustainability: A Model of

Commissioning System Intervention

in Supporting Multi-Stakeholder

Partnerships from National to Global

Levels. Sustainability 2022, 14, 1536.

https://doi.org/10.3390/

su14031536

Academic Editor: Luigi Aldieri

Received: 8 January 2022

Accepted: 26 January 2022

Published: 28 January 2022

Publisher's Note: MDPI stays neutral with regard to jurisdictional claims in published maps and institutional affiliations.

Copyright: (C) 2022 by the authors. Licensee MDPI, Basel, Switzerland. This article is an open access article distributed under the terms and conditions of the Creative Commons Attribution (CC BY) license (https:// creativecommons.org/licenses/by/ $4.0 /)$.

\author{
Management and Computer Sciences Department, Faculty of Economic Sciences and Business Administration, \\ Transilvania University of Brasov, 500036 Brasov, Romania; tiberiu.foris@unitbv.ro \\ * Correspondence: camelia.dragomir@unitbv.ro
}

\begin{abstract}
The paper addresses the role of intermediaries in optimizing collaborative practices for sustainability and provides new perspectives on how the commissioning system intervenes in supporting multi-stakeholder partnerships that operate on different geographical scales. We present in this study a unitary model for the development of the commissioning system with geographically hierarchical structures, from local and national to regional and global levels, capable of creating a network of interdependent connections with international potential between a wide range of parties engaged in collaboration for sustainable territorial development. The paper highlights the potential of the commissioning system to provide better support for sustainability partnerships and identifies the roles that commissioning structures can play for the benefit of the parties interested in mobilizing and accessing capabilities and resources for development. Through its intervention, the collaborative actions between the parties are streamlined and the management of demands and offers of development resources is optimized. Our findings show that such an intervention adds value to partnerships for sustainability at regional and global levels by dynamizing the collaboration, exchange and transfer of resources between the states, using functional collaboration networks created among multiple interacting stakeholders to support the sustainable development goals implementation.
\end{abstract}

Keywords: sustainable development; multi-stakeholder partnerships; intermediary; commissioning system; management structures of the commissioning

\section{Introduction}

Contemporary society is marked by major economic, social and environmental issues, and identifying the most appropriate solutions to address them requires new approaches and roles for all parties interested in sustainability, from all sectors of society and at all levels. No one can be left alone in the face of these issues and solving them is a challenge that must be addressed through a jointly coordinated global effort in a long-term vision of sustainable performance and development [1-3]. The scale, complexity and interdependence of sustainable development goals included in the 2030 Agenda call on all stakeholders, governments, intergovernmental organizations and non-state actors in all sectors of society to get involved and work collaboratively, sharing knowledge, technology, expertise and other relevant resources to create value for sustainability for the benefit of society as a whole [4-6]. At all levels, collaborative commitments to sustainability are recognized as necessary to effectively address the complex issues of sustainable development that go beyond the capacity of organizations and their management [7-9] or that of the authorities to address them on their own $[10,11]$. In particular, multi-stakeholder partnerships bringing together actors from different sectors of society (public, private, non-profit) to work together for sustainability, combining resources and sharing risks, are seen as an effective way to address current challenges of sustainable development [12]. These partnerships can act locally, nationally, regionally and globally and are supported by a broad coalition of international 
and national actors, from the public and private sectors, non-governmental organizations and academia that jointly support the achievement of the Sustainable Development Goals (SDGs) [13]. Especially in the case of these partnerships, the specialists highlighted significant added value for joint actions to contribute to the SDGs, while generating benefits for all the parties involved, related to the easier access to knowledge, resources, networks, opportunities [14-17] and a better awareness of the dimensions of sustainability concerning the society [18-20]. Despite all the benefits, several factors can pose real challenges to the proper functioning of the partnerships for sustainability [21-23], especially when the stakeholders are from different social sectors and regions of the world, with different levels of development, priorities and possibilities [24-26]. At a large geographical, regional or global scale, these partnerships have their own set of challenges with greater complexity. They bring together a wide range of stakeholders with different approaches and capabilities and must be relevant to countries with varied expectations, priorities and needs [27]. Many contextual economic, political, geographical, historical or cultural elements [28,29] can affect the interaction of the parties and can create a "nuanced mix in different situations and moments that affect partnerships" [5]. The various and multiple difficulties can be limited by the intervention of intermediaries, who can act as partnership brokers [30-33], bridging agents [34-36], commissionaires [37,38] or relationship builders [39] for the parties working together to achieve sustainable development goals [40]. In theory and practice, the role of intermediaries is recognized and appreciated as significant for the efficient functioning of multi-stakeholder collaboration for sustainability [5,25,41,42]. Their intervention helps partners to identify the need to collaborate, to create collaborative networks and to guide their joint actions to achieve the goals set [31,43].

Although the literature provides a representative number of studies dedicated to collaborating with several stakeholders for sustainability and the role of intermediaries in this context, there is limited research on intermediation systems and their intervention in supporting partnerships for sustainable territorial development. This paper continues the research of the authors on the role of intermediaries in optimizing collaborative practices for sustainability and provides new perspectives on how the commissioning system intervenes in supporting collaboration for sustainability by setting a unitary intervention framework of commissioning structures from local and national levels to regional and global ones. The study highlights the potential of the commissioning system to support multi-stakeholder partnerships for sustainability that operate on different geographical scales and identifies the roles that commissioning structures can play for the benefit of the parties mobilizing capabilities and resources to respond to sustainability challenges. The specific objectives pursued in this paper take into account: designing the conceptual model for the development of a globally interoperable commissioning system with geographically hierarchical structures to support partnerships for sustainability with several stakeholders; describing the rationale for the development of the model and the principles of system operation at the national, regional and global levels; discussing the implications that the implementation of this system may have for optimizing collaboration at the level of partnerships for sustainability and highlighting the benefits for a wide range of parties involved in collaborative practices; establishing future directions for the study development.

The concept of commissioning refers to a series of specialized services that can be provided by professional commissioners to individuals or legal entities based on contractual relations, in the name and on behalf of clients or in their name but for the account of them [37]. In this study, the commissioners are entities specialized in development areas and priorities (industry, agriculture, health, education, etc.) that provide professional services to managing the demands and offers of development resources for a wide range of stakeholders, actors from different sectors of society and at different levels of governance, involved in collaborating for the sustainable development of a specific geographical region [38]. More specifically, commissioning structures mobilize and manage the demands and offers of development resources from a wide range of stakeholders for sustainable development on their electronic platforms, interconnect and harmonize information and 
perform search operations to operatively identify the most suitable offer for solving sustainability issues for which the demands were launched, supporting the connection between the parties interested in their capitalization. This paper aims at deepening the study on the intervention of commissioning organizations in the collaboration with multiple stakeholders for sustainable territorial development, by extending the model for the structural and systemic development of commissioning from the national level, as presented in our previous research, to the regional and global levels. This approach involves bringing together a wide range of stakeholders, governments, intergovernmental organizations and non-state actors to share knowledge, skills, expertise and other essential resources to find solutions to sustainability issues for the benefit of society as a whole.

The research conducted in this paper started with the systemic challenges faced by the parties involved in various forms of collaboration for sustainability in terms of mobilizing, managing, accessing and capitalizing on development resources. In particular, for addressing global sustainability issues, identifying the right tools and intervention framework for supporting regional and global sustainability partnerships is a challenge for all stakeholders and requires new approaches and solutions to be considered. The configuration and development of systems and structures that allow network interaction between a wide range of actors collaborating to achieve sustainable development goals are more and more discussed $[15,44]$. These systems can provide more support to the parties than an individual intermediary, especially in the case of extended partnerships which involve actors from different sectors of society and different geographical areas. This finding is in line with other specialized studies emphasizing that intermediation systems are more useful in facilitating the connection between the parties involved in various forms of collaboration for sustainability $[1,25,45]$. In this context, we believe that our paper contributes to the development of the current state of knowledge on collaborative approaches to sustainability and expands the perspective of studying the role of intermediaries in supporting multi-stakeholder partnerships for sustainable territorial development. The main contribution of the research is supported by the design of a unitary model for the development of the commissioning system with geographically hierarchical structures, capable of creating a network of interdependent connections with international potential between governments at all levels and with all relevant stakeholders engaged in partnerships to support the sustainable development goals implementation. The recognition that the sustainable development goals (SDGs) set out in the UN program - the 2030 Agenda provide the necessary climate for collaboration and solidarity on the exchange and transfer of resources essential for global sustainable development is highly relevant to this study [4]. We believe that the internationalization of the commissioning system responds to the call of the 2030 Agenda on consolidating regional and global partnerships for sustainable development by creating a framework conducive to collaboration, exchange and transfer of resources for development between states, taking into account their specific development needs and issues. Given the principle of leaving no one behind, the intervention of commissioning structures can help states to expand their collaborative practices by mobilizing available resources for the benefit of less developed countries to reduce the economic and social inequalities among nations. Therefore, the design and development of the commissioning system based on the model presented in the paper is a possible intervention solution in supporting multi-stakeholder partnerships for sustainability and has favorable implications for all parties involved, facilitating their access to resources, contacts and functional collaboration networks to achieve the sustainable development goals.

The paper is further structured as follows: Section 2 highlights the importance of global collaboration for building a sustainable society in light of the sustainable development goals. Section 3 discusses the extension of the structural development model of the commissioning system from national to regional and global levels and explains its operating and intervention principles. Section 4 discusses the relevance of the internationalization of the commissioning system for optimizing collaboration processes at the level of regional 
and global partnerships for sustainable development. Future contributions, implications and research are highlighted. Section 5 presents the conclusions of the study.

\section{Global Collaboration for Sustainability-The Mandatory Path for a Sustainable Common Future}

Global collaboration for sustainability has become an increasingly important topic in academic, political, social and business debates and is considered an opportunity for all stakeholders to share responsibilities in addressing the most pressing challenges of building a sustainable future for the world we live in [27,46-48]. The multiple issues involved in sustainable development at a global level, from economic growth and employment to environmental protection and solving social problems, must be addressed using an integrative vision and solving them requires joint efforts, by engaging a wide range of stakeholders brought together in collaborative commitments for sustainability. A growing number of experts from all areas recognize the key role of global collaboration for sustainability, enabling the various state and non-state actors to expand their efforts for sustainable development beyond national borders and mobilize the skills and resources needed to solve economic, social and environmental problems that profoundly affect the well-being and progress of mankind [49-51].

The implementation of advanced sustainable development goals and targets in UN policy statements emphasizes the need to create "sustainable partnerships between governments at all levels and with all relevant stakeholders, including the private sector, civil society, academic environment" [4,52] to align human society to the global path of sustainable development. The 2030 Agenda has maximized the interest of the states for global collaboration and solidarity in line with the principles of sustainability and paved the way for creating and strengthening regional and global partnerships for sustainable development [53-55]. Concretely, under Goal 17 for Sustainable Development, "Strengthening the means of implementing and revitalizing the global partnership for sustainable development", Goal 17.6 refers to the need to strengthen regional and international cooperation on "access to science, technology, innovation and to improve knowledge exchange under mutually agreed conditions" [4]. Furthermore, Goal 17.16 explicitly mentions the need to strengthen and revitalize the global partnership for sustainable development, supplemented by "multi-stakeholder partnerships that mobilize and share knowledge, expertise, technology" to support the achievement of sustainable development goals in all countries of the world, especially in developing countries [4,5]. Achieving the 17 Goals of the 2030 Agenda is an ambitious and extremely challenging global project of "transforming our world" [13,56-58]. We are all part of a globalized world and solving the problems raised by sustainable development must be seen as a common project based on the solidarity between states and mutual support in terms of resources for development: knowledge, technology, expertise, financial resources [59-61]. No nation can ignore what is happening outside its borders and each must play its part in the joint effort to put human society on a more sustainable development path [62-64]. Each country faces specific development problems and, therefore, there is a need for solidarity and collaborative partnerships between the parties that produce, mobilize and transfer resources for development and those that request these resources to reduce inequalities and respect one of the fundamental principles of the 2030 Agenda, that of leaving no one behind $[4,65]$. Following this principle, SDGs should be implemented especially for the weak and marginalized to ensure more sustainable and inclusive growth [66]. It is a road that the states of the world, developed and less developed countries, must take together and that implies an overarching common vision on how to address the issues of sustainability to reduce economic and social inequalities and provide access to relevant development resources for less developed countries [67-69]. For this purpose, the internationalization of the commissioning system can be a way to stimulate the exchange and transfer of resources for development between the states of the world, helping to reduce the gap of knowledge, technology and other relevant 
resources between different levels of governance from local and national to regional and international communities.

\section{Internationalization of the Commissioning System. Extending the Model of Structural and Systemic Development of Commissioning from National to Regional and Global Levels}

This part aims at extending the structural development model of the commissioning system from the national level, as suggested in our previous research [38], to the regional and global levels. The model proposed in this section highlights, using the interdependencies described, the potential of the commissioning system to create functional collaboration networks between a wide range of parties engaged in sustainability partnerships operating at different geographical scales (locally, nationally, regionally, globally). The concept of an intermediation system supporting collaborative actions for sustainability and the design of its development model with geographically hierarchical structures has been generated by the various and multiple difficulties faced by the parties involved in partnerships to achieve sustainable development goals in a specific geographical area. The identified issues frequently refer to the difficult process of mobilizing, managing and capitalizing on the demands and offers of resources launched by state and non-state actors that come together to face the challenges of sustainable development at the territorial level [38]. In particular, at the level of the public-private partnership for sustainability, the involved parties have highlighted the low efficiency of the management process of demands and offers for development resources. Using its structures, the commissioning system provides stakeholders with professional services for the operative intermediation of demands and offers of development resources, ensuring their management and operative identification of appropriate offers, using its computer platforms to solve the sustainability issues for which the demands were launched. Hence, the parties interested in accessing or providing resources save time and effort, being relieved of the task of searching and identifying the best solutions for their development needs, with commissioning entities taking over this task performed operationally, using fast and secure computer systems capable of creating efficient and prompt connections. To explain the principles underlying the internationalization of the commissioning system, we start from the structural development model of the system designed at the country level. The model was conceived for the territorial-administrative structure of Romania, with commissioning entities that operate at the level of cities (CL), metropolitan areas $(\mathrm{CM})$, counties $(\mathrm{CC})$ and state level $(\mathrm{CN})$, because the starting point for authors in designing the model was the systemic challenges faced by Romanian governmental and local authorities and non-state actors involved in collaborative arrangements for sustainability. They mainly emphasized the difficulties encounter from the perspective of the difficult process of mobilization, management and capitalization of demand and supply of resources to meet the sustainable development objectives set at the territorial level. We considered that the example is welcomed to describe the principles of system operation at the country level. This does not change the idea behind the conceptualization of the suggested model for the creation of a large-scale interoperable commissioning system, namely the bottom-up approach, from local and national to regional and global levels.

At the country level, the model describes the principles of system operation at the national level and how it intervenes to support the public-private partnership for sustainability between governmental and territorial authorities which launch demands for resources to achieve sustainable development goals set by public policies and non-state actors from different sectors of society, interested in submitting offers and mobilizing capabilities and resources to meet these demands. Using its geographically hierarchical structures, the commissioning system ensures the connection between involved parties and facilitates the efficient and operative interconnection of demands and offers for each geographical area. The commissioning structures can be monitored by public territorial authorities (city halls, county councils) or can operate independently. At the national level, the model includes a central structure of the commissioning system $(\mathrm{CN})$ which can be monitored at the governmental level (for example, by a ministry with responsibilities for 
sustainable development). The configuration of the model allows both the connection between the commissioning structures and the parties involved in collaborative agreements for sustainable development on a territorial scale, as well as between the structures of the system, which operate at the territorial-administrative level. Between the latter, the interconnection takes place both horizontally, between the commissioning entities operating at the same administrative-territorial level (city, metropolitan area or county) and vertically, between the entities operating at higher or lower, different territorial-administrative levels. The interconnection procedure has a neural form (Figure 1).

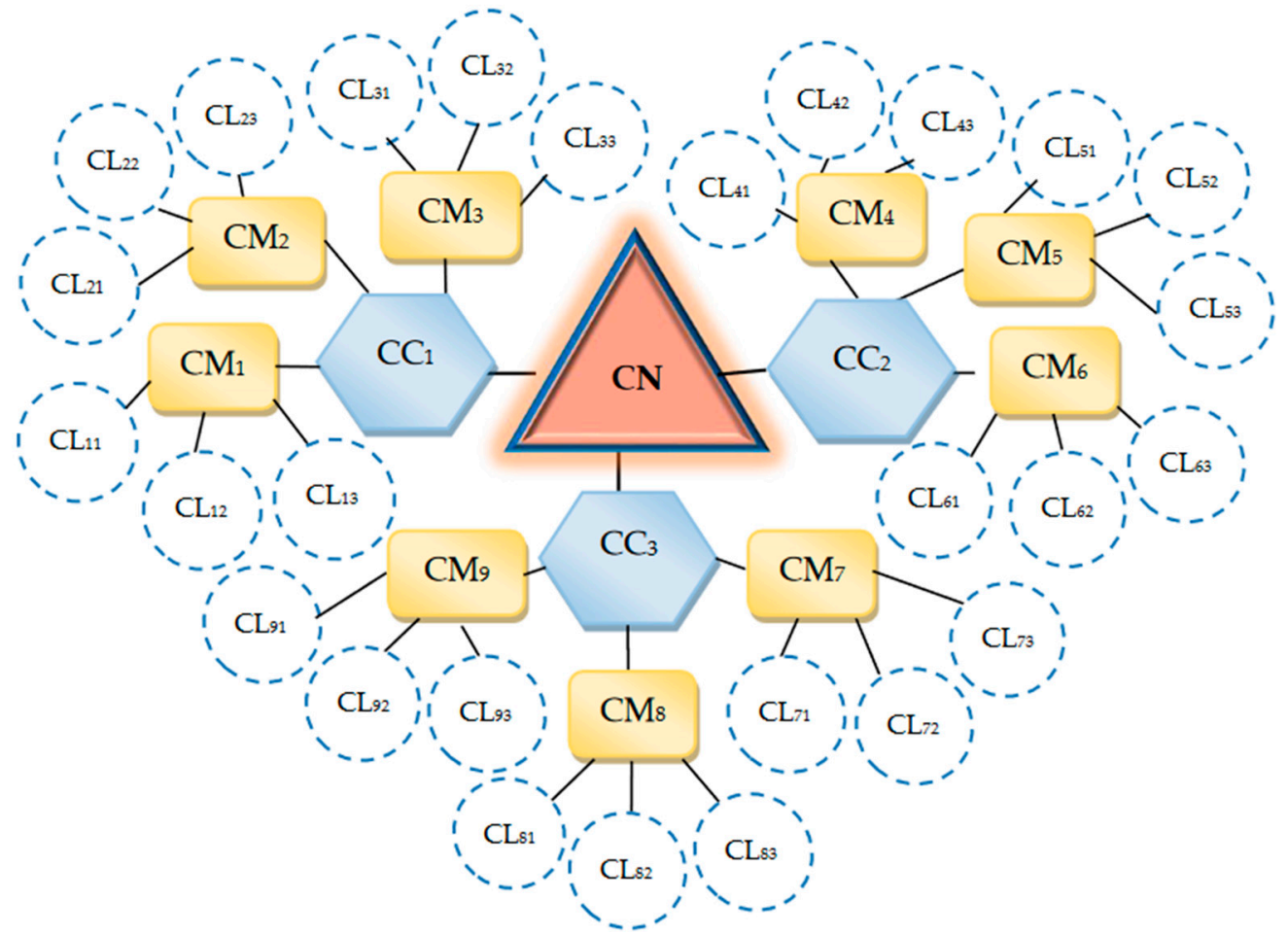

Figure 1. The neural structure of commissioning at the level of national interconnection; $\mathrm{CL}_{11} \ldots \mathrm{CL}_{1 \mathrm{n}}$; $\mathrm{CL}_{21} \ldots \mathrm{CL}_{2 \mathrm{n}} ; \mathrm{CL}_{\mathrm{n} 1} \ldots \mathrm{CL}_{\mathrm{nn}}$ - the specialized structures of commissioning at the cities level; $\mathrm{CM}_{1} ; \mathrm{CM}_{2}$ $\ldots . \mathrm{CMn}$ - the specialized structures of commissioning at the metropolitan areas level; $\mathrm{CC}_{1} ; \mathrm{CC}_{2} \ldots$ $\mathrm{CCn}$-the specialized structures of commissioning at the level of the counties; $\mathrm{CN}$-the management structure of the commissioning at the national level.

The commissioning entities concentrate in their computer platforms the demands and offers launched at the territorial level, organize them in interoperable databases specialized in areas and development priorities, harmonize the information and ensure the operative identification of suitable offers to solve sustainability issues for which the demands have been submitted, using the horizontal interconnection. If the corresponding offer is not identified by the horizontal interconnection, the commissioning structures operating vertically in the system and at a higher level will be accessed up to the central structure $(\mathrm{CN})$ which concentrates the entire offers mobilized at the national level.

In this way, all the elements of the relationship between the structures of the system and between them and the stakeholders work optimally and the process of collecting, managing and capitalizing on demands and offers on a national scale is carried out efficiently and operationally in a secure environment.

Extrapolating the reasoning from the national level, we extend the structural development model of the system at the regional level and further globally. The regional level considered in this study refers to countries in the same geographical area or belonging to the same geo-economic and political area (for example, the European Union). At this level, the model includes a central regional structure $(\mathrm{CR})$ which concentrates the entire demands 
and offers for development resources of the states involved in the regional partnership for sustainable development, interested in accessing or allocating resources to solve specific sustainability issues and implement SDGs. There is an interconnection and mutual access to databases between the national commissioning structures $(\mathrm{CNn})$ and between them and the regional structure, to allow the regional structure to access and analyze the information registered by each national structure and to operatively identify the appropriate offer to solve each sustainability issue for which demands have been launched. The functional connections of the national commissioning structures are made directly with the central regional structure. The interconnection procedure is neural from the level of national structures to the level of the regional structure (Figure 2). Structured in this way, the system facilitates the connection between the demands and offers of resources launched by the parties and simplifies the process of searching, identifying and transferring development resources between them.

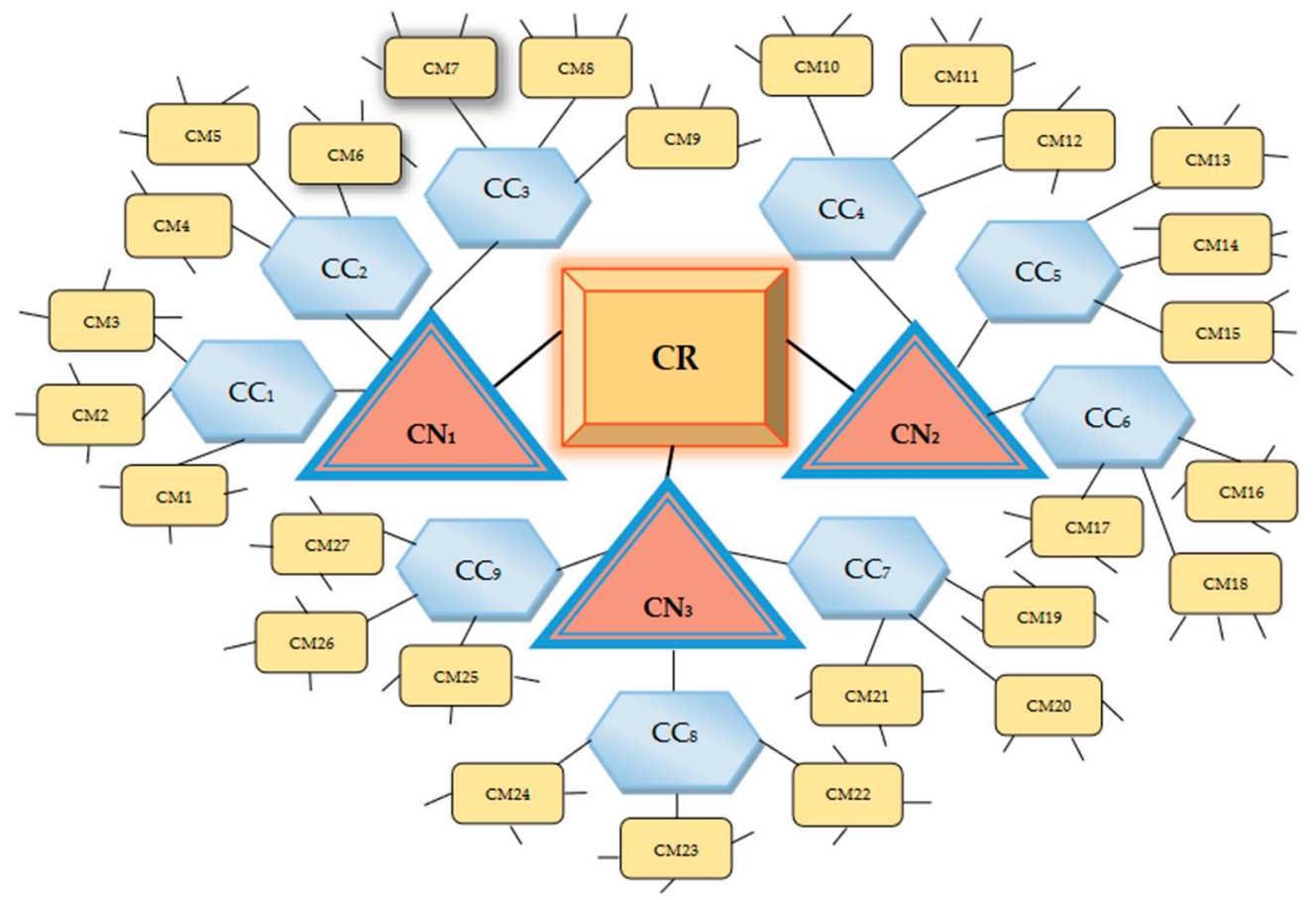

Figure 2. The neural structure of commissioning at the level of regional interconnection; $\mathrm{CN}_{1} \ldots$ $\mathrm{CN}_{\mathrm{n}}$ - the specialized structures of commissioning at the level of the countries; CR-the management structure of commissioning at the regional level.

The reasoning behind the development of the model observes the same principles for the structural connection of the global commissioning system (Figure 3).

At this scale, the system includes a global structure (CM) as a central element, which can be accessed by all states involved in global collaborative agreements to achieve sustainable development goals. This structure mobilizes and concentrates the offers and demands for development resources launched by the countries engaged in the partnership, analyses the information, identifies the appropriate offer for each demand launched in the system, in collaboration with the regional structures $(\mathrm{CRn})$, and facilitates the connection between the parties interested in capitalizing on them. CM is interconnected with all regional structures in the system, providing a key focal point for concentrating information to and from them so that the entire supply of knowledge, technology, expertise and other resources relevant to sustainability, which has been mobilized at the level of structures in the system, is available to respond the demands launched for solving the sustainability issues. The internationalization of the commissioning system aims at providing global interoperability at the level of the global commissioning structure (CM), between the platforms made available by the national $(\mathrm{CNn})$ and regional $(\mathrm{CRn})$ structures, thus creating the premises for building a global 
cloud to concentrate the supply of knowledge and other development relevant resources submitted to its platforms and which stakeholders can use for the operational identification of the best solutions to development issues, in response to the demands they submitted to the system. In this way, the commissioning structures facilitate the connection between the parties launching the demands and offers for development and operatively identify the appropriate solutions to solve the development issues for which the demands have been submitted, using the progressive search at the level of territorial structures, following the analysis of the data from their platforms. Structured in this way, the commissioning system can create a network of interdependent connections with international potential between the states of the world and ensure an orderly and well-structured environment for collecting, managing and operationally capitalizing on demands and offers of resources that enables the achievement of the sustainable development goals. The functional relations between the commissioning structures and the parties using their services are based on a contract which will stipulate strict clauses regarding the confidentiality of information, the level of the commission charged, the payment formula (which can be paid once, pay per use, etc.). The implementation of the system involves strict regulations on operational (legal, logistic, infrastructure, management, etc.) and use conditions (licenses, security protocols, taxes, etc.). The major challenge in the global implementation of the commissioning system lies in the differences between countries in terms of network communications, interoperability of systems and database security. Solving this issue requires identifying technical solutions that allow the interconnection of the IT systems of the national commissioning structures in such a way that the data associated with these systems are shared between stakeholders, regardless of the technology used in their creation. Concerning the security factors of communication and data storage, the IT platforms provided by the commissioning structures are designed as an area of integrating the demand and supply for development resources, with an interconnection component based on secure WEB services (for example, REST/JSON), which can ensure the collection, management, sharing of demand and supply for development resources and also the security and control over communication and data storage. Access to the platforms owned by commissioning structures will also be based on standard protocols on data security and safety. However, the absence of global standards for interoperability and data security can raise issues concerning the internationalization of the commissioning system. The applicability of the model on a global scale implies the existence of a favorable legislative framework to harmonize international regulations and norms on network communications and data security. At the same time, the fees for services provided by commissioning structures can raise a series of issues related to different economic conditions and states development levels. Developing countries may not be able to afford the professional services provided by commissioning structures without additional financial support. For this purpose, national governments of developed states in close cooperation with international institutions, especially the UN, could establish conditions to facilitate the access of these countries to the services of the system and thus to the supply of available development resources concentrated on its platforms. The implementation of the commissioning system, as a tool to support global cooperation and achieve the SDGs, requires significant commitments from governmental authorities and international institutions on support mechanisms for involving vulnerable states in functional and inclusive partnerships. Finally, it is a matter of common understanding and will of national governments and international bodies, which must be reflected in convincing actions to provide real support for the 2030 Agenda call. In the context of our discussion, we refer to the encouragement of support structures such as interoperable multi-stakeholder systems that can bring the states of the world together for the common goal of sustainable global development. 


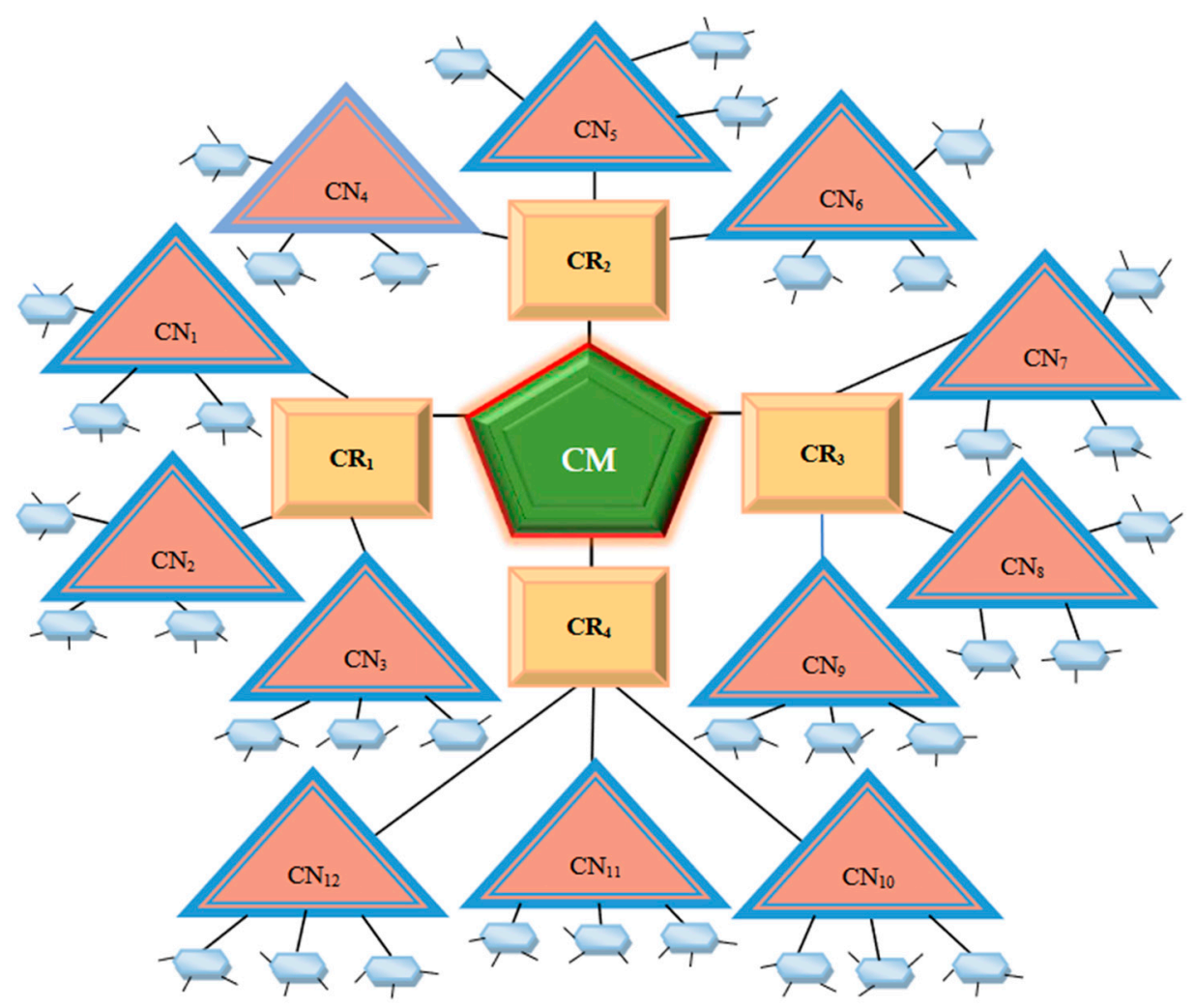

Figure 3. The neural structure of commissioning at global interconnection; $\mathrm{CR}_{1}, \mathrm{CR}_{2} \ldots \mathrm{CRn}$ - the specialized structures of commissioning at the level of the regions; $\mathrm{CM}$ - the management structure of commissioning at the global level.

\section{Discussion}

\subsection{Implications}

The collaboration for sustainability is considered an opportunity for all stakeholders to mobilize and transfer capabilities and resources for development and to share responsibilities in facing the most pressing challenges of building a prosperous and sustainable society $[70,71]$. However, multi-stakeholder partnerships for sustainability often face difficulties, especially when these collaborative arrangements operate on a large geographical scale $[16,72]$. One solution for optimizing collaborative actions is the intervention of intermediaries, who support and facilitate the connection between the parties and identify their interests and needs on time to support activities and help mobilize them around a common vision [58,73]. At the level of regional and global partnerships for sustainability, the challenge of finding effective intervention mechanisms and tools for supporting the interaction of parties mobilizing capabilities and resources to face sustainability challenges is high. We have tried to respond this challenge by setting up a unitary model for the structural development of the commissioning system from a national level to regional and global ones to provide better support for multi-stakeholder partnerships to achieve sustainable development goals. Concerning the contribution to the literature, few studies address intermediaries as vectors of sustainable territorial development. Our research expands the flow of knowledge in this field of study and opens up new perspectives on how the intervention of intermediation systems adds value to regional and global sustainability collaboration by supporting stakeholders to better interact to meet their responsibilities and commitments to support the sustainable development goals implementation. The study highlights that the development of the commissioning system with geographically hierarchical structures can be an effective way to support partnerships for sustainable territorial development due to its potential to create functional collaboration networks on different geographical scales between multiple actors interested in mobilizing and transferring resources for 
development. The finding is consistent with other studies in the literature that suggest the favorable implications of collaborative networks for the success of multi-stakeholder partnerships for development $[1,25]$. To this end, several researchers support the design and development of interoperable systems that allow networking of actors from different sectors, working together to achieve the goals of sustainable development $[44,45,74]$.

We consider that its implementation has favorable implications for the effectiveness of joint actions for sustainability and benefits for the parties involved. Through its intervention, the collaborative actions between the parties are streamlined by reducing the time needed to identify appropriate offers to solve sustainability issues and the process of collecting, managing and capitalizing on demands and offers of resources is optimized. The fact that the commissioning intervention can be more than a liaison between the parties mobilizing demands and offers of development resources is just as important. Using the structures that operate regionally and globally, commissioning can support underdeveloped countries by directly engaging in specific projects to support those states in addressing their economic, social and environmental issues, providing them increased access to new contacts and resources to help them deliver national priorities under the SDGs. Based on the demands for resources mobilized in its platforms, commissioning identifies the real development needs of the respective communities and can start building a partnership by identifying and convening stakeholders to mobilize available expertise and resources to perform a specific task and work together to aid local capacities building. In other words, identifying development issues in poor regions of the world, promoting the idea of partnership and calling on stakeholders to mobilize and transfer resources to support specific projects that vulnerable communities cannot complete by themselves, underline the broad implications of commissioning for the benefit of development interests of the states, taking into account the territorial needs and priorities. More specifically, the development of the commissioning system, as presented in the paper, can support the alignment of states with the spirit of global collaboration and solidarity supported by the 2030 Agenda to reduce economic and social inequalities and "leave no one behind" [4]. Using the intervention of commissioning structures, developed countries can be encouraged to expand their collaborative practices, mobilizing knowledge, technology, expertise and other available resources for the benefit of poor and vulnerable countries to develop and support development programs taking into account their specific needs. First and foremost, governments need to be aware of the potential benefits of this system and encourage the initiative to create it by setting up the necessary legal framework regulating its organization, structure and operation. In this regard, our study can help decision-makers responsible for setting and achieving territorial sustainable development goals to gain a deeper understanding of the potential of this system to mobilize skills and resources for sustainable development from a wide range of actors from all sectors of society. In particular, at the level of the public-private partnership for sustainability, the operation of the commissioning system based on the principles of the suggested model can support the connection between public authorities, which set sustainable development goals and launch demands for development resources and non-state actors interested in mobilizing capabilities and resources to respond sustainability challenges in a specific geographical region. Authorities can also benefit from assistance in shaping and elaborating territorial sustainable development goals and strategies, with commissioning organizations being able to provide information on the offers of development resources launched and mobilized by non-state actors on their platforms. In this way, the local and governmental authorities are supported in fulfilling their responsibilities and commitments regarding the achievement of the SDGs at their level of governance. In addition, using their specialists, the commissioning organizations can provide consultancy and counseling services to the parties involved in collaborative commitments concerning the best solutions to solve sustainability issues in a specific field and on a certain geographical scale, as well as forecasts of the expected results following their implementation, based on the analysis of data from their platforms. These assessments can be used by the management of the entities engaged in partnership and can underline 
strategic management measures regarding their involvement in collaborative arrangements for sustainability, to take into account how stakeholders are directly affected by their sustainability efforts. Previous research has also highlighted the fact that organizations providing intermediation functions for multi-stakeholder partnerships for sustainability have multiple roles, usually offering consultancy and support services [25,33]. The engagement of non-state actors, particularly the private sector, in collaborative partnerships to achieve the SDGs is considered a representative attribute for responsible sustainable behavior, with favorable effects on organizational performance and successful management practices $[75,76]$. This finding is supported by previous research $[9,15,22]$ that has highlighted the opportunities and benefits for non-state actors involved in multi-stakeholder partnerships for the implementation of the SDGs. In this regard, several authors have indicated improved efficiency and innovation $[77,78]$ as well as easier access to knowledge, networks and other opportunities [14,24,79].

The relevance of the commissioning system can be highlighted also in other collaborative contexts, supporting stakeholders in developing specific business models. Entities from different sectors and geographical areas can benefit from the potential of this system that can be used in this direction. From our point of view, the interoperability offered by the commissioning system creates value for a wide range of parties interested in developing collaborative business arrangements on an international scale by improving their business models. This finding is consistent with current studies showing that the interoperability of IT platforms provides opportunities for collaborative business practices [80,81]. The research highlights the benefits of interoperable platforms for the management of companies in various business sectors (industry, trade, research, health, etc.) that can come together to share knowledge, technology and develop successful business models [82,83]. This approach offers new perspectives on how to use the interoperability of the commissioning system and broadens the scope of future research.

\subsection{Future Research Directions}

The proposed conceptual model paves the way for further research that will allow new directions of development. Future studies could further examine the implications of the commissioning system intervention for optimizing collaborative actions at the level of multi-stakeholder partnerships for sustainability and the benefits for all parties involved. We intend to examine the impact of the commissioning system intervention and the effects on stakeholders, local public authorities and non-state actors, who come together to face sustainability challenges at this level. In this respect, we aim at firstly testing it on a small scale within a public-private partnership to achieve the sustainable development goals in a specific geographical area of Romania (for example, county). We intend to extend the study to the examination of several ways of economic use of the commissioning system and the opportunities arising from its implementation. We aim at conducting quantitative research to obtain a larger volume of data from more organizational stakeholders interested in using the services of the commissioning system. Following the processing and statistical analysis, these data will provide a more comprehensive picture of the functionality of this model by assessing a set of indicators that reflect the performance of the commissioning system concerning the number of users, the level of fees charged, the revenue stream, etc. In particular, we consider it interesting and relevant for our research to extend the study to examine the interoperability of this model with other business models. The evolution of information and communication technology (ICT) has increased the interest in collaborative business arrangements on a global scale by setting up specific business models. Further research can make a significant contribution to the development of sustainable business models based on the implementation of IT platforms (e.g., IoT business models) that can benefit from the interoperability provided by the commissioning system. The development of this research direction will prove that there are several possibilities to use the suggested model for the internationalization of the commissioning system and to extend its impact in various sectors of activity that develop collaborative business models based on digital 
platforms. We believe that the interoperability of the suggested model broadens the scope of the commissioning system and provides opportunities for all parties involved in an interoperable ecosystem. The effectiveness of the commissioning system must be certainly proved in practice. We aim at testing the model by implementing it in a real context and using the method of multiple case studies in future research. Consequently, quantitative and qualitative approaches to mixed research methods will continue to support further developments in several research directions.

Finally, the exploration of these ideas can be relevant on a large scale, especially in the context of the intense concern to find the most appropriate mechanisms and tools of intervention for supporting the multiple stakeholders that come together in collaborative actions for sustainability at different geographical scales to generate the transformative changes implied by the achievement of the SDGs.

\section{Conclusions}

The starting point of this paper was the current global context affected by multiple and complex economic, social and environmental issues that contemporary society has to face. Sustainable development cooperation is seen as a viable solution to the new challenges posed by this context and the intervention of intermediaries is recognized as a key factor in optimizing collaborative practices between a wide range of parties working together to effectively tackle these issues. Considering new approaches to identifying effective intervention mechanisms and tools to support collaboration for sustainability is a challenge for all those responsible for achieving implementing the SDGs at all levels of governance. In this study, we presented a possible intervention formula for supporting partnerships for sustainability that operate on different geographical scales, by designing a unitary model for the development of the commissioning system with geographically hierarchical structures, from local and national to regional and global levels, to streamline the process of mobilizing, managing and transferring resources between a wide range of parties engaged in collaboration for sustainable territorial development. The model proposed in this paper highlights, using the interdependencies described, the potential of the commissioning system to create functional collaboration networks between a wide range of parties engaged in sustainability partnerships operating at different geographical scales (locally, nationally, regionally, globally). The operation of the system, based on the principles of the suggested model, can ensure an orderly and well-structured environment for collecting, managing and operationally capitalizing on demands and offers of resources that enables the achievement of the sustainable development goals. Our findings emphasize highlight the potential of the commissioning system to provide better support for sustainability partnerships and identify the roles that commissioning structures can play for the benefit of the parties interested in mobilizing and accessing capabilities and resources for development. Through its intervention, the collaborative actions between the parties are streamlined by reducing the time needed to identify appropriate offers to solve sustainability issues and the management of demands and offers of development resources is optimized. Our study shows that the internationalization of the commissioning system adds value to collaboration for sustainability at regional and global levels by dynamizing the collaboration, exchange and transfer of resources between the states, using a network of interdependent connections created among multiple interacting stakeholders to achieve the sustainable development goals. Furthermore, the global interoperability of the system can be used by non-state actors in the private sector to expand their collaborative business practices internationally by setting up sustainable business models. In this regard, we believe that the interoperability of the suggested model broadens the scope of the commissioning system and provides opportunities for all parties involved in an interoperable ecosystem. As indicated in this paper, future studies are needed to analyze the organizational and operational framework of the system, taking into account all aspects that affect its functionality. The implementation of the system involves strict regulations on operational (legal, logistic, infrastructure, management, etc.) and use conditions (licenses, security protocols, fees, etc.). The absence 
of global standards for interoperability and data security can raise issues concerning the internationalization of the commissioning system. There is a need for legislative alignment of states and harmonization of national regulations in this field. We also discussed issues that may arise from the perspective of the development gap between states and the limited possibilities of poor countries to access and pay the commissioning services. In this regard, we believe that additional financial support is needed for these countries and the involvement of the governments of developed countries and international institutions, especially the UN, to facilitate their access to these services and thus the supply of available resources concentrated in its platforms. The internationalization of the commissioning system is based on strong collaboration mechanisms, a high level of responsibility, confidence and mutual support of all states involved in collaboration commitments to jointly address the global sustainable development problems. However, although the commissioning system developed based on the suggested model has the potential to support collaborative actions for sustainable development at the international level, it is by no means a remedy for settling all economic and commercial tensions between countries. Its efficient functioning depends on an environment conducive to global collaboration for achieving the SDGs, the national governments' real political will in this direction and an internationally harmonized legislative framework on the interoperability of systems and databases for supporting the intervention of commissioning structures at this scale. The relevance of contextual factors for the operation of the system at this level requires examination in future research, taking into account its specific mode of operation. Therefore, this study serves as a first step in drawing the attention of all key stakeholders, governments, local authorities, business practitioners and researchers alike to the potential of the commissioning system to become an effective intervention tool in supporting multi-stakeholder collaboration for sustainability from the local and national levels to regional and global ones.

Author Contributions: Conceptualization, C.-C.D.; methodology, C.-C.D., T.F.; investigation, C.-C.D., T.F.; writing-original draft preparation, C.-C.D.; writing-review and editing, C.-C.D., T.F.; visualization, C.-C.D., T.F. All authors have read and agreed to the published version of the manuscript.

Funding: This research has been supported by funding from Transilvania University of Brasov, Romania.

Institutional Review Board Statement: Not applicable.

Informed Consent Statement: Not applicable.

Data Availability Statement: Not applicable.

Conflicts of Interest: The authors declare no conflict of interest.

\section{References}

1. Camarinha-Matos, L.M.; Afsarmanesh, H.; Boucher, X. The Role of Collaborative Networks in Sustainability. In Collaborative Networks for a Sustainable World; Camarinha-Matos, L.M., Afsarmanesh, H., Boucher, X., Eds.; Springer: Berlin/Heidelberg, Germany, 2010; pp. 1-16, ISBN 978-3-642-15960-2. [CrossRef]

2. Griggs, D.; Stafford-Smith, M.; Gaffney, O.; Rockström, J.; Öhman, M.C.; Shyamsundar, P.; Steffen, W.; Glaser, G.; Kanie, N.; Noble, I. Sustainable development goals for people and planet. Nature 2013, 495, 305-307. [CrossRef] [PubMed]

3. Sachs, J.D. The Age of Sustainable Development; Columbia University Press: New York, USA, 2015; ISBN 978-0-231-17315-5.

4. United Nations (UN). Transforming Our World: The 2030 Agenda for Sustainable Development; United Nations: New York, NY, USA, 2015. Available online: https://sustainabledevelopment.un.org/post2015/transformingourworld (accessed on 15 December 2021).

5. Melo, V. Collaborative Efforts for Sustainable Development: Surveying the Literature on Multistakeholder Initiatives to Realize the Sustainable Development Goals. Task Team. 2018. Available online: https://taskteamcso.com/wp-content/uploads/2019/0 4/Task-Team-Full-Literature-Review.pdf (accessed on 15 December 2021).

6. Grainger-Brown, J.; Malekpour, S. Implementing the Sustainable Development Goals: A Review of Strategic Tools and Frameworks Available to Organisations. Sustainability 2019, 11, 1381. [CrossRef]

7. Gimenez, C.; Tachizawa, E.M. Extending sustainability to suppliers: A systematic literature review. Supply Chain Manag. 2012, 17, 531-543. [CrossRef]

8. Fobbe, L. Analysing Organisational Collaboration Practices for Sustainability. Sustainability 2020, 12, 2466. [CrossRef] 
9. Lozano, R.; Barreiro-Gen, M.; Zafar, A.; Lozano, R. Collaboration for organizational sustainability limits to growth: Developing a factors, benefits, and challenges framework. Sustain. Dev. 2021, 29, 728-737. [CrossRef]

10. Ayala-Orozco, B.; Rosell, J.A.; Merçon, J.; Bueno, I.; Alatorre-Frenk, G.; Langle-Flores, A.; Lobato, A. Challenges and strategies in place-based multi-stakeholder collaboration for sustainability: Learning from experiences in the Global South. Sustainability 2018, 10, 3217. [CrossRef]

11. Seitanidi, M.M. Adaptive responsibilities: Non-linear interactions across social sectors-Cases from cross sector social partnerships. Emerg. Complex. Org. J. 2008, 10, 51-64.

12. Hemmati, M. Principles for Multi-Stakeholder Processes. In Stakeholder Democracy; Dodds, F., Ed.; Routledge: New York, NY, USA, 2019; pp. 194-211, ISBN 978-0815386933.

13. Beisheim, M.; Ellersiek, A. Partnerships for the 2030 Agenda for Sustainable Development: Transformative, Inclusive and Accountable? SWP Research Paper; German Institute for International and Security Affairs (SWP): Berlin, Germany, 2017. Available online: https:/ / www.swp-berlin.org/publications / products/research_papers/2017RP14_bsh_elk_01.pdf (accessed on 15 December 2021).

14. Kuenkel, P.; Aitken, A. Key Factors for the Successful Implementation of Stakeholder Partnerships: The Case of the African Cashew Initiative. In The Business of Social and Environmental Innovation; Springer: Berlin/Heidelberg, Germany, 2015; pp. 183-197. [CrossRef]

15. Banerjee, A.; Murphy, E.; Walsh, P.P. Perceptions of Multistakeholder Partnerships for the Sustainable Development Goals: A Case Study of Irish Non-State Actors. Sustainability 2020, 12, 8872. [CrossRef]

16. Stibbe, D.; Prescott, D. An Introduction to Multi-Stakeholder Partnerships; The Partnering Initiative: Oxford, UK, 2016. Available online: https://thepartneringinitiative.org/publications/research-papers/an-introductionto-multi-stakeholder-partnerships/ (accessed on 20 December 2021).

17. Sharma, A.; Kearins, K. Interorganizational collaboration for regional sustainability: What happens when organizational representatives come together? J. Appl. Behav. Sci. 2011, 47, 168-203. [CrossRef]

18. Lozano, R. Collaboration as a pathway for sustainability. Sustain. Dev. 2007, 381, 370-381. [CrossRef]

19. Freudenreich, B.; Lüdeke-Freund, F.; Schaltegger, S. A Stakeholder theory perspective on business models: Value creation for sustainability. J. Bus. Ethics 2020, 166, 3-18. [CrossRef]

20. Pugel, K.; Javernick-Will, A.; Koschmann, M.; Peabody, S.; Linden, K. Adapting Collaborative Approaches for Service Provision to Low-Income Countries: Expert Panel Results. Sustainability 2020, 12, 2612. [CrossRef]

21. Keyton, J.; Ford, D.J.; Smith, F.L. A mesolevel communicative model of collaboration. Commun. Theory 2008, 18, 376-406. [CrossRef]

22. Larsson, J.; Larsson, L. Integration, Application and Importance of Collaboration in Sustainable Project Management. Sustainability 2020, 12, 585. [CrossRef]

23. Bryson, J.M.; Crosby, B.C.; Stone, M.M. Designing and implementing cross-sector collaborations: Needed and challenging. Public Adm. Rev. 2015, 75, 647-663. [CrossRef]

24. Pattberg, P.; Widerberg, O. Theorising global environmental governance: Key findings and future questions. Millennium 2015, 43 , 684-705. [CrossRef]

25. Stadtler, L.; Probst, G. How broker organizations can facilitate public-private partnerships for development. Eur. Manag. J. 2012, 30, 32-46. [CrossRef]

26. Fadeeva, Z. Promise of sustainability collaboration-Potential fulfilled? J. Clean. Prod. 2005, 13, 165-174. [CrossRef]

27. Steven, D.; Kashambuzi, E. Turning Ambition into Reality: Platforms and Partnering for Delivering Agenda 2030; New York University Center on International Co-operation: New York, NY, USA, 2016. Available online: https://cic.nyu.edu/sites/default/files/ turning_ambitions_steven_kashambuzi_final_web_2.pdf (accessed on 20 December 2021).

28. Selsky, J.W.; Parker, B. Cross-sector partnerships to address social issues: Challenges to theory and practice. J. Manag. 2005, 31, 849-873. [CrossRef]

29. Utting, P.; Zammit, A. United Nations-business partnerships: Good intentions and contradictory agendas. J. Bus. Ethics. 2009, 90, 39-56. [CrossRef]

30. Moreno-Serna, J.; Sánchez-Chaparro, T.; Mazorra, J.; Arzamendi, A.; Stott, L.; Mataix, C. Transformational Collaboration for the SDGs: The Alianza Shire's Work to Provide Energy Access in Refugee Camps and Host Communities. Sustainability 2020, 12, 539. [CrossRef]

31. Tennyson, R. What Do Partnership Brokers Do? In Shaping Sustainable Change: The Role of Partnership Brokering in Optimising Collaborative Action, 1st ed.; Stott, L., Ed.; Routledge: Abington, UK, 2018; pp. 20-34, ISBN 9781783537365.

32. Howells, J. Intermediation and the role of intermediaries in innovation. Res. Policy. 2006, 35, 715-728. [CrossRef]

33. Lee, L. Understanding the Role of the Broker in Business Non-Profit Collaboration. Soc. Responsib. J. 2015, 11, 201-220. [CrossRef]

34. Pilorget, L. Innovation consultancy services in the European community. Int. J. Technol. Manag. 1993, 8, 687-696.

35. Meyer, M. The Rise of the Knowledge Broker. Sci. Commun. 2010, 32, 118-127. [CrossRef]

36. Manning, S.; Roessler, D. The formation of cross-sector development partnerships: How bridging agents shape project agendas and longer-term alliances. J. Bus. Ethics 2014, 123, 527-547. [CrossRef]

37. Cismaru, I.; Petrescu, I.; Dragomir, C.; Cismaru, L. Commissionaireing system internationalization: Certainty vector in sustainable development. Transform. Bus. Econ. 2017, 16, 21-33. 
38. Dragomir, C.-C.; Foriş, D.; Ţîţu, A.M.; Foriş, T. The Role of Intermediaries in Supporting Collaboration for Sustainability: A Model of Commissioning Intervention in the Multi-Stakeholder Collaboration for Sustainable Territorial Development. Sustainability 2020, 12, 6769. [CrossRef]

39. Bardach, E. Getting Agencies to Work Together: The Practice and Theory of Managerial Craftsmanship; The Bookings Institution Press: Washington, DC, USA, 1998; ISBN 9780815707974.

40. Vurro, C.; Dacin, M.T.; Perrini, F. Institutional antecedents of partnering for social change: How institutional logics shape cross-sector social partnerships. J. Bus. Ethics. 2010, 94, 39-53. [CrossRef]

41. Mignon, I.; Kanda, W.A. Typology of Intermediary Organizations and Their Impact on Sustainability Transition Policies. Environ. Innov. Soc. Transit. 2018, 29, 100-113. [CrossRef]

42. Johnson, V.; Brennan, L. Using infomediaries to build effective networks between business and society. Corp. Gov. 2007, 7, 301-311. [CrossRef]

43. Bush, R.E.; Bale, C.S.; Powell, M.; Gouldson, A.; Taylor, P.G.; Gale, W.F. The Role of Intermediaries in Low Carbon TransitionsEmpowering Innovations to Unlock District Heating in the UK. J. Clean. Prod. 2017, 148, 137-147. [CrossRef]

44. Worley, C.G.; Mirvis, P.H. Studying Networks and Partnerships for Sustainability: Lessons Learned. In Building Networks and Partnerships; Organizing for Sustainable Effectiveness; Worley, C.G., Mirvis, P.H., Eds.; Emerald Group Publishing Limited: Bingley, UK, 2013; Volume 3, pp. 261-291. [CrossRef]

45. Méndez-Suárez, M.; Monfort, A.; Gallardo, F. Sustainable Banking: New Forms of Investing under the Umbrella of the 2030 Agenda. Sustainability 2020, 12, 2096. [CrossRef]

46. Köhler, J.; Geels, F.; Kern, F.; Markard, J.; Wieczorek, A.; Alkemade, F.; Avelino, F.; Bergek, A.; Boons, F.; Fuenfschilling, L.; et al. An Agenda for Sustainability Transitions Research: State of the Art and Future Directions. Environ. Innov. Soc. Transit. 2019, 31, 1-32. [CrossRef]

47. Global Reporting Initiative (GRI) G4 Sector Disclosures. Available online: https:/ /www.globalreporting.org/information/sectorguidance/Pages/default.aspx (accessed on 28 December 2021).

48. Sachs, J.D.; Schmidt-Traub, G.; Mazzucato, M.; Messner, D.; Nakicenovic, N.; Rockström, J. Six transformations to achieve the sustainable development goals. Nat. Sustain. 2019, 2, 805-814. [CrossRef]

49. Stafford-Smith, M.; Griggs, D.; Gaffney, O.; Ullah, F.; Reyers, B.; Kanie, N.; Stigson, B.; Shrivastava, P.; Leach, M.; O'Connell, D. Integration: The key to implementing the Sustainable Development Goals. Sustain. Sci. 2017, 12, 911-919. [CrossRef] [PubMed]

50. Paletta, A.; Fava, F.; Ubertini, F.; Bastioli, C.; Gregori, G.; La Camera, F.; Douvan, A.R. Universities, industries and sustainable development: Outcomes of the 2017 G7 Environment Ministerial Meeting. Sustain. Prod. Consum. 2019, 19, 1-10. [CrossRef]

51. Van Hille, I.; de Bakker, F.G.; Ferguson, J.E.; Groenewegen, P. Cross-Sector Partnerships for Sustainability: How Mission-Driven Conveners Drive Change in National Coffee Platforms. Sustainability 2020, 12, 2846. [CrossRef]

52. The United Nations, General Assembly Resolution 60/214; United Nations. Multi-stakeholder Partnerships for Sustainable Development. High-Level Political Forum on Sustainable Development, Issue Briefs, No. 3. 2014. Available online: https: / / sustainabledevelopment.un.org/content/documents/1312HLPF_Brief_3.pdf (accessed on 28 December 2021).

53. Kanie, N.; Griggs, D.; Young, O.; Waddell, S.; Shrivastava, P.; Haas, P.M.; Broadgate, W.; Gaffney, O.; Korösi, C. Rules to goals: Emergence of new governance strategies for sustainable development. Sustain. Sci. 2019, 14, 1745-1749. [CrossRef]

54. Dodds, F. Multi-Stakeholder Partnerships: Making Them Work for the Post-2015 Development Agenda. Global Research Institute, University of Carolina. Available online: http://www.un.org/en/ecosoc/newfunct/pdf15/2015partnerships_background_note. pdf (accessed on 28 December 2021).

55. Jovovic, R.; Draskovic, M.; Delibasic, M.; Jovovic, M. The concept of sustainable regional development-Institutional aspects, policies and prospects. J. Int. Stud. 2017, 10, 255-266. [CrossRef]

56. del Mar Alonso-Almeida, M.; Llach, J.; Marimon, F. A closer look at the 'Global Reporting Initiative'sustainability reporting as a tool to implement environmental and social policies: A worldwide sector analysis. Corp. Soc. Responsib. Environ. Manag. 2014, 21, 318-335. [CrossRef]

57. United Nations (UN). The Sustainable Development Goals Report 2018; United Nations: New York, NY, USA, 2018. Available online: https://unstats.un.org/sdgs/files/report/2018/TheSustainableDevelopmentGoalsReport2018-EN.pdf (accessed on 28 December 2021).

58. Gray, B.; Purdy, J. Collaborating for Our Future: Multistakeholder Partnerships for Solving Complex Problems; Oxford University Press: Oxford, UK, 2018; ISBN 978-0198782841.

59. Stibbe, D.T.; Reid, S.; Gilbert, J. The Partnering Initiative and United Nations Department of Economic and Social Affairs. 2019. Available online: https://sustainabledevelopment.un.org/content/documents/2564Partnerships_for_the_SDGs_Maximising_ Value_Guidebook_Final.pdf (accessed on 28 December 2021).

60. Rosati, F.; Faria, L.G. Addressing the SDGs in sustainability reports: The relationship with institutional factors. J. Clean. Prod. 2019, 215, 1312-1326. [CrossRef]

61. Atkisson, A. Multi-Stakeholder Partnerships in the Post-2015 Development Era: Sharing Knowledge and Expertise to Support the Achievement of the Sustainable Development Goals. Background Paper Convened by UN-DESA. Available online: https: //sustainabledevelopment.un.org/content/documents/7366Partnerships_Knowledge_BackgroundPaper_final.pdf (accessed on 28 December 2021). 
62. McQuaid, R. The Theory of Partnership: Why Have Partnerships. In Public-Private Partnerships. Theory and Practice in International Perspective; Osborne, O., Ed.; Routledge: New York, NY, USA, 2000; pp. 9-35, ISBN 9780429229671.

63. Horan, D. A new approach to partnerships for SDG transformations. Sustainability 2019, 11, 4947. [CrossRef]

64. Abrahamsen, R. The power of partnerships in global governance. Third World Q. 2004, 25, 1453-1467. [CrossRef]

65. Morse, S.; McNamara, N. The universal common good: Faith-based partnerships and sustainable development. J. Sustain. Dev. 2009, 17, 30-48. [CrossRef]

66. United Nations (UN). The Road to Dignity by 2030: Ending Poverty, Transforming all Lives and Protecting the Planet. Synthesis Report of the Secretary-General on the Post-2015 Sustainable Development Agenda, United Nations: New York, NY, USA. Available online: https://www.un.org/disabilities/documents/reports/SG_Synthesis_Report_Road_to_Dignity_by_2030.pdf (accessed on 2 January 2022).

67. Kolk, A. Partnerships as Panacea for Addressing Global Problems. In Social Partnerships and Responsible Business: A Research Handbook; Seitanidi, M., Crane, A., Eds.; Routledge: New York, NY, USA, 2013; pp. 15-41, ISBN 9780415678643.

68. Patscheke, S.; Barmettler, A.; Herman, L.; Overdyke, S.; Pfitzer, M. Shaping global partnerships for a post-2015 world. Stanf. Soc. Innov. Rev. 2014, 9, 2-9. [CrossRef]

69. Brown, D.L. Bridge-building for social transformation. Stanf. Soc. Innov. Rev. 2015, 13, 34-39. [CrossRef]

70. Stadtler, L. Scaling up tripartite social partnerships, insights from the becoming perspective on change. J. Corp. Citizsh. 2016, 63, 96-118. [CrossRef]

71. Taylor, J. Understanding international partnerships, a theoretical and practical approach. Perspect. Policy Pract. High. Educ. 2016, 20, 44-50. [CrossRef]

72. Pattberg, P.; Widerberg, O. Transnational multistakeholder partnerships for sustainable development: Conditions for success. Ambio 2016, 45, 42-51. [CrossRef]

73. Hamann, R.; April, K. On the Role and Capabilities of Collaborative Intermediary Organisations in Urban Sustainability Transitions. J. Clean. Prod. 2013, 50, 12-21. [CrossRef]

74. McEvily, B.; Zaheer, A. Architects of Trust: The Role of Network Facilitators in Geographical Clusters. In Trust and Distrust in Organizations; Kramer, R., Cook, K., Eds.; Russell Sage Foundation: New York, NY, USA, 2004; pp. 189-213.

75. Santos, E.; Moreira, J. Social Sustainability of Water and Waste Management Companies in Portugal. Sustainability $2022,14,221$. [CrossRef]

76. Morioka, S.N.; Bolis, I.; Evans, S.; Carvalho, M.M. Transforming sustainability challenges into competitive advantage: Multiple case studies kaleidoscope converging into sustainable business models. J. Clean. Prod. 2017, 167, 723-738. [CrossRef]

77. Steijn, B.; Klijn, E.H.; Edelenbos, J. Public private partnerships: Added value by organizational form or management? Public Adm. 2011, 89, 1235-1252. [CrossRef]

78. Provan, K.G.; Kenis, P. Modes of network governance: Structure, management, and effectiveness. J. Public Adm. Res. Theory 2008, 18, 229-252. [CrossRef]

79. Austin, J.E.; Seitanidi, M.M. Collaborative value creation: A review of partnering between nonprofits and businesses: Part I. Value creation spectrum and collaboration stages. Nonprofit Volunt. Sect. Q. 2012, 41, 726-758. [CrossRef]

80. Schladofsky, W.; Mitic, J.; Megner, A.P.; Simanto, C.; Gioppo, L.; Leonardos, D.; Bröring, A. Business Models for Interoperable IoT Ecosystems. In Interoperability and Open-Source Solutions for the Internet of Things. InterOSS-IoT 2016. Lecture Notes in Computer Science; Žarko, I.P., Broering, A., Soursos, S., Serrano, M., Eds.; Springer: Berlin/Heidelberg, Germany, 2017 ; pp. 91-106. [CrossRef]

81. Baden-Fuller, C.; Haefliger, S. Business Models and Technological Innovation. Long Range Plan. 2013, 46, 419-426. [CrossRef]

82. Zhao, Y.Y.; von Delft, S.; Morgan-Thomas, A.; Buck, T.W. The evolution of platform business models: Exploring competitive battles in the world of platforms. Long Range Plan. 2020, 53, 101892. [CrossRef]

83. Yang, K.H. Equivalence in Business Models for Informational Intermediaries. IO: Theory eJournal. Available online: https: / / ssrn.com/abstract=3457015 (accessed on 7 January 2022). 